Nova Southeastern University

Florida

NOVA SOUTHEASTERN

UNIVERSTYY

NSUWorks

Marine \& Environmental Sciences Faculty Articles Department of Marine and Environmental Sciences

$3-1-2015$

\title{
Migration Strategies Vary in Space, Time, and Among Species in the Smallfish Metacommunity of the Everglades
}

J. Matthew Hoch

Florida International University; Nova Southeastern University, jhoch@nova.edu

Eric R. Sokol

Florida International University; Virginia Tech

Aaron D. Parker

Florida International University; Michigan Department of Environmental Quality

Joel C. Trexler

Florida International University

Find out more information about Nova Southeastern University and the Halmos College of Natural Sciences and Oceanography.

Follow this and additional works at: https://nsuworks.nova.edu/occ_facarticles

Part of the Marine Biology Commons, and the Oceanography and Atmospheric Sciences and Meteorology Commons

\section{NSUWorks Citation}

J. Matthew Hoch, Eric R. Sokol, Aaron D. Parker, and Joel C. Trexler. 2015. Migration Strategies Vary in Space, Time, and Among Species in the Smallfish Metacommunity of the Everglades .Copeia , (1) : $157-169$. https://nsuworks.nova.edu/occ_facarticles/500.

This Article is brought to you for free and open access by the Department of Marine and Environmental Sciences at NSUWorks. It has been accepted for inclusion in Marine \& Environmental Sciences Faculty Articles by an authorized administrator of NSUWorks. For more information, please contact nsuworks@nova.edu. 


\title{
Migration Strategies Vary in Space, Time, and Among Species in the Small-fish Metacommunity of the Everglades
}

\author{
J. Matthew Hoch ${ }^{1,2}$, Eric R. Sokol ${ }^{1,3}$, Aaron D. Parker ${ }^{1,4}$, and Joel C. Trexler ${ }^{5}$
}

\begin{abstract}
Spatial ecology and movement strategies of aquatic organisms may limit their response to human-caused drying of wetland habitats. We characterized the movement strategies of the most abundant species of fish in the wetlands of the Everglades (USA) to better understand how they cope with annual fluctuations in aquatic habitat size. Over a sixyear period, we used a sampling method designed to measure the density, activity levels, and movement direction of small fishes. We estimated changes in displacement speed and directional bias to identify patterns of movement that different fishes use to disperse over the gradient of disturbance in this environment. Movement of fishes ranged from highly active and directed to passive and random, and varied with hydrological condition (water rising, stable, or dropping). Six of the eight species studied displayed "directed" movement (possibly displaying taxis along environmental gradients) that varied in both speed and directional blas in response to hydrological cues. The remaining two species did not adjust the direction that they moved in response to hydrological cues, but their activity levels increased. Moving with directional blas may improve a fish's chance of early arrival in a newly available habitat or of escaping the risk of desiccation in drying wetlands. Fishes that change activity levels may improve their likelihood of reaching favorable environments by increasing diffusion rates and greater sampling of the environment. Interspecific variation in movement strategles is predicted to play a large role in community structure and may be a primary driver of the dynamics of the Everglades fish metacommunity.
\end{abstract}

$\mathrm{D}$ ISPERSAL dynamics can play a large role in determining spatial and temporal trends in diversity in ecosystems that experience regular disturbance. The Everglades (Florida, USA; Fig. 1) is a large, karstic wetland subject to Caribbean climatic cycles yielding seasonal periods of flooding and drying (Davis, 1943; Fennema et al., 1994; Gunderson, 1994). Draining and water diversions shortened hydroperiods throughout the ecosystem for most of the $20^{\text {th }}$ century, which has led to the initiation of a major restoration initiative largely aimed at recovering historical hydrology to the greatest extent possible (Light and Dineen, 1994; National Research Council, 2007). Though with great uncertainty, climate change scenarios mostly predict a drier future climate in southern Florida, reinforcing the need to efficiently use water for environmental benefits (Pearlstine et al., 2010). Furthermore, maintenance of groundwater levels are seen as the only practical way to slow impacts from sea-level rise that are already affecting South Florida and are expected to continue (Pearlstine et al., 2010).

Small fish with annual life cycles play a central role in the food-web ecology of the Everglades, where they are prey for apex predators such as wading birds, alligators, and larger fishes. Empirical diversity patterns for these fish are driven by a variety of factors across spatial and temporal scales, but the annual rise and fall of water levels is foremost among them (Trexler et al., 2001). Large portions of the landscape dry each year, eliminating local populations where drying occurs (Fennema et al., 1994; DeAngelis et al., 1997, 2010; Trexler et al., 2001). Sub-regions of varying hydrologic conditions can be thought of as patches within a metacommunity (Trexler et al., 2005). Management and sustenance of apex predators in the future Everglades is thought to be tied to the productivity and spatial ecology of small fish and macroinvertebrate communities that are strongly tied to ongoing water management, past water extraction, and future restoration (Trexler and Goss, 2009). Understanding the behavioral ecology of fish dispersal is a fundamental step to predicting the benefits of responses to current and future challenges of water management in the Everglades (Yurek et al., 2013).

Recent modeling studies on the re-populating of newly flooded portions of the Everglades have focused on the dynamics of fish dispersal and migration (DeAngelis et al., 1997, 2010; Jopp et al., 2010). Passive dispersal by fish entrained in water currents is unlikely in the Everglades system, owing to extremely low current speeds and because the direction of flow is perpendicular to the direction of wetland re-flooding (Ho et al., 2009). Remnant populations in small, local refuges (like solution holes or alligator ponds) may supply a recruitment base during re-colonization (Loftus et al., 1992; Gaff et al., 2000), but their population sizes are far too low to contribute much to the recolonization (Kobza et al., 2004; DeAngelis et al., 2010). Models comparing re-colonization rates from random diffusion with directed migrations (movement biased in the direction of the flooding front) of fish from a large, permanent, water body suggest that directed migrations must occur to supply the biomass observed in re-flooded areas (DeAngelis et al., 2010; Jopp et al., 2010). These directed migrations may be driven by fish moving with taxis toward newly available food resources along the flooding front, resulting in a dynamic ideal free distribution (DeAngelis et al., 2010). Fishes may also change their activity levels (speed, turning frequency, or step length-defined as sustained movement in one direction) in response to

\footnotetext{
${ }^{1}$ Southeast Environmental Research Center, Florida International University, Miami, Florida 33181.

${ }^{2}$ Present address: Division of Math, Science and Technology, Nova Southeastern University, Ft. Lauderdale, Florida 33314; E-mail: jhoch@nova.edu. Send reprint requests to this address.

${ }^{3}$ Present address: Department of Biological Sciences, Virginia Tech, Blacksburg, Virginia 24061; E-mail: sokole@gmail.com.

${ }^{4}$ Present address: Michigan Department of Environmental Quality, Surface Water Assessment Section, Lansing, Michigan 48909; E-mail: parkerA7@michigan.gov.

${ }^{5}$ Department of Biological Science, Florida International University, Miami, Florida 33181; E-mail: trexlerj@fiu.edu.

Submitted: 28 February 2014. Accepted: 17 June 2014. Associate Editor: J. F. Schaefer.

(C) 2015 by the American Society of Ichthyologists and Herpetologists DOI: 10.1643/CE-14-040 Published online: March 5, 2015
} 


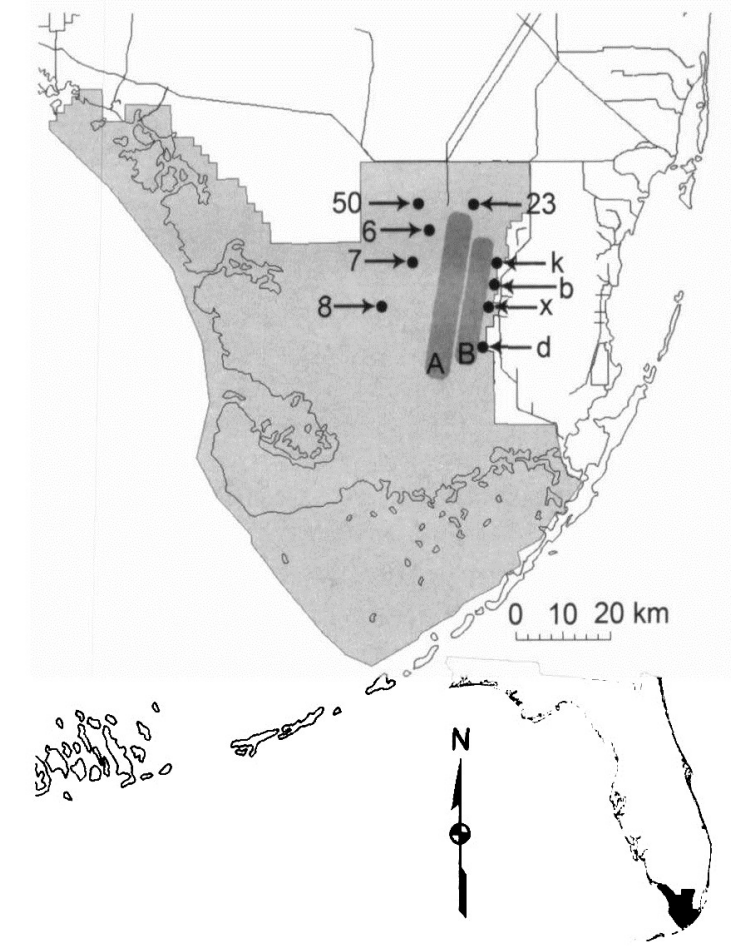

Fg. I. The light shaded area shows Everglades National Park. The darker shaded areas show areas used in comparisons of fish population density as measured by throw trapping; A: Short-A, B: Short-B. Black points label drift-fence sites; numbered sites as labeled, $k$ : Chekika, $x$ : Context Road, b: S332B, d: S332D.

changing water levels. This may lead to the arrival of fish in re-opened habitats faster than purely random movement, but more slowly than directed migration, serving as a less efficient mechanism by which fish approach a dynamic ideal free distribution.

Directed movement by animals can be of major importance for metapopulation and metacommunity dynamics (Armsworth and Roughgarden, 2005; Abrams et al., 2007; Jacobson and Peres-Neto, 2010). Animals moving with directional bias orient their movement toward a specific cue, whereas randomly moving organisms do not orient behavior (distance traveled, turning rate, or turning angle) in response to cues (Armsworth and Roughgarden, 2005). Taxis, focused movement toward or away from a cue, yields strongly directional displacement (Schick et al., 2008). Directed movement appears to be common in animals from butterflies (Conradt et al., 2000) to sharks (Papastamatiou et al., 2011). Alternatively, organisms may respond to cues by changing activity (increasing speed and distance moved in a single bout, or increasing turning angle and turning rate), but not the specific direction of movement. Lévy flights (movement paths whose step lengths have heavy-tailed distributions, resulting in occasional, very long steps) may result from this behavior (Viswanathan et al., 1996). These behaviors are thought to increase search efficiency. Biphasic movement patterns (resulting from changes in gross activity level) have been observed in elk (Cervus elaphus), which show "searching" movements when attempting to locate favorable habitats and "encamped" movements once they arrive in one (Morales et al., 2004). Two common fish from the Everglades, Eastern Mosquitofish (Gambusia holbrooki) and Flagfish (Jordanella floridae), display distinct pulses of activity that correspond to wetland drying and reflooding, punctuated by periods of lower activity (Goss et al., 2013).
Fish immigration (Snodgrass et al., 1996; Baber et al., 2002; Hohausová et al., 2010) and emigration (Poizat and Crivelli, 1997; Cucherousset et al., 2007; Henning et al., 2007; Parkos et al., 2011) to and from temporary wetlands have been well documented in several ecosystems. These migrations tend to be observed at narrow transition points between the temporary wetland and more permanent water. In the Everglades, temporary wetlands are continuous with more permanent water, creating a complex landscape over which fish must move to and from temporary habitat. The population dynamics of small fishes in the Everglades landscape have been assessed using long-term data obtained by throw trapping (Trexler et al., 2001, 2005; Ruetz et al., 2005). While fish movement was implicit in those studies, the direction and magnitude of movement was not measured because the small size of the fish precludes tracking individuals by standard methods.

We used encounter samplers (Obaza et al., 2011) to assess the magnitude of activity and the direction of movement of small fish. We sought to ascertain the behavior of fishes at sites of different disturbance intensity (frequency and intensity of marsh-drying) and at different times relative to the disturbance (during the periods of drying, stability, and subsequent re-flooding). We addressed two goals by testing the null hypotheses: 1) fish activity and movement direction does not vary between long and short-hydroperiod habitats and 2) fish activity and movement direction does not vary seasonally (wet vs. dry). If fish movement is random, we expect to see no difference in encounter rates or directionality between hydroperiod regions or among seasons. Fish following these patterns are likely to die from stranding during drying and to be the slowest to recolonize sites after reflooding. If the direction of fish movement is random, but activity levels change (possibly reflecting behavior similar to Lévy flights), we expect to see greater encounter rates in regions with short hydroperiods or during periods of change in water levels, but no directional bias. We predict that more active fishes will encounter a larger proportion of the environment, have a greater likelihood of locating favorable habitat (like reflooded sites and dry-season refuges), and move between hydroperiod regions more quickly than fishes that do not change activity levels. If fish move with directional bias, we expect differences in capture of fish traveling in one direction in different hydroperiod regions or as water levels change. These fishes will be the fastest colonizers of newly opened habitat and the most likely to escape region-level disturbances, such as marsh dry-downs.

\section{MATERIALS AND METHODS}

Study system.-This study took place in the Shark River Slough drainage of Everglades National Park (Fig. 1). The region is composed of wet-prairies, characterized by spikerush (Eleocharis cellulosa), maidencane (Panicum spp.), and beakrush (Rhynchospora spp.) with slightly topographically higher ridges dominated by sawgrass (Cladium jamaicense; Loveless, 1959; Gunderson, 1994). The system is pulsed with water during the wet season, which lasts from about May to November (DeAngelis, 1994; Duever et al., 1994). Sawgrass ridges and wet-prairie sloughs form a braided hydroscape oriented parallel to the direction of water flow, but perpendicular to the direction that water expands and contracts (Ho et al., 2009; Larsen and Harvey, 2010). Thus, 


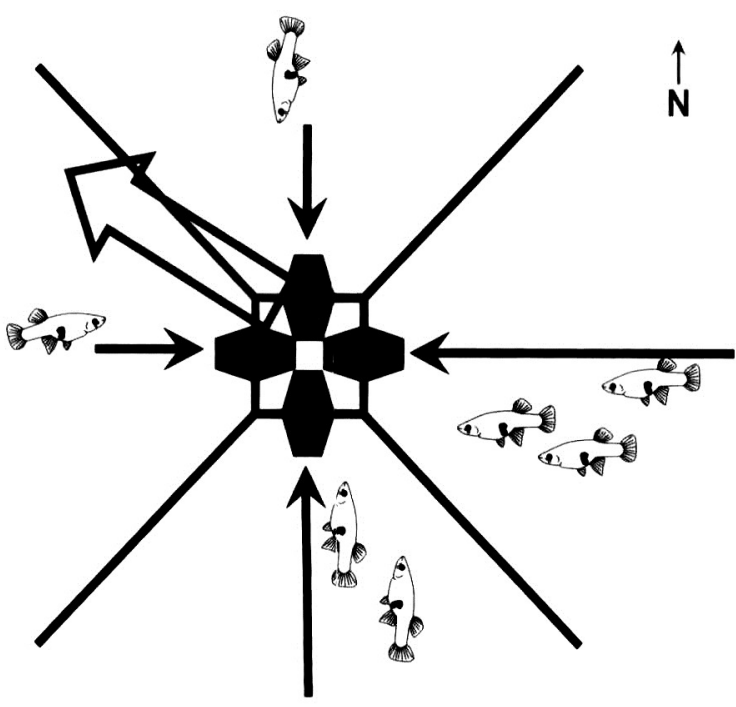

Fig. 2. Schematic diagram of a drift fence (not to scale) and example of how bias in directional movement was calculated. The drift fences had traps facing north, south, east, and west and captured fishes traveling from those directions. The numbers of fish captured in each minnow trap was treated as the magnitude of vectors oriented in the direction that the trap faces. The magnitude of the averaged vector was used as "bias," here shown as an open arrow in gray.

available habitat for fishes expands and contracts, sometimes at a rapid rate (DeAngelis et al., 1997).

For small fishes in the Everglades, methods for direct study of movement (tagging, direct observation, etc.) are impractical owing to dense vegetation and their small size. The expansive and open landscape of the Everglades precluded trapping at choke-points in the habitat (as in Poizat and Crivelli, 1997; Cucherousset et al., 2007; Henning et al., 2007). When attempted, recapture rates of marked fishes was very low (unpubl. data). We used indirect methods to estimate the directionality of moving fishes by use of drift fences, similar to fence traps used to quantify directional movement of insects, mammals, herpetofauna, and other animals (see Obaza et al., 2011 and references therein).

Collections.-Fishes were captured with unbaited, $3 \mathrm{~mm}$ wire-mesh minnow traps (entrance diameter $=25 \mathrm{~mm}$ ) embedded in drift fences (see Obaza et al., 2011 for complete construction methods and technical evaluation). The fences were constructed from four sheets of plastic ground-cloth, $12 \mathrm{~m}$ long and up to $1.5 \mathrm{~m}$ tall, supported by posts. These were sewn to the corners of a central, square-shaped fence (also made of ground-cloth, $1.5 \mathrm{~m}$ per side) with each side facing a cardinal direction. The four fences extended at 45 degree angles from the corner of the central square, forming an " $\mathrm{X}$ " when viewed from above (Fig. 2). Moving fishes were corralled into the traps facing their direction of origin. We sampled traps when water depths were between $15 \mathrm{~cm}$ (the minimum depth at which the minnow trap openings were submerged) and the height of the fence. Potential bias in capture may result from escape and avoidance by fish, predation within the trap, and other local influences (He and Lodge, 1990; Dupuch et al., 2011; Obaza et al., 2011). We made the assumption that these biases were constant over the landscape and would equally affect results from different hydroperiod regions. The size of fishes capable of being caught in the traps was limited to those with a body diameter between the wire mesh size of $3 \mathrm{~mm}$, and the
Table 1. Sites, their classification, and the numbers of samples collected from each.

\begin{tabular}{lcccc}
\hline Sites & $\begin{array}{c}\text { Hydro- } \\
\text { period }\end{array}$ & $\begin{array}{c}\text { Drift fence } \\
(\boldsymbol{n})\end{array}$ & $\begin{array}{c}\text { Drift fence } \\
\text { trap-nights }\end{array}$ & $\begin{array}{c}\text { Throw } \\
\text { traps }(\boldsymbol{n})\end{array}$ \\
\hline 6 & Long & 2 & 59 & 20 \\
7 & Long & 2 & 60 & 5 \\
8 & Long & 2 & 50 & 23 \\
23 & Long & 2 & 65 & 20 \\
50 & Short & 2 & 42 & 19 \\
S332B & Short & 6 & 133 & 0 \\
S332D & Short & 6 & 220 & 0 \\
Context Road & Short & 2 & 20 & 0 \\
Chekika & Short & 2 & 6 & 0 \\
Short-A & Short & 0 & $n / a$ & 10 \\
Short-B & Short & 0 & $n / a$ & 13 \\
& & & & \\
\hline
\end{tabular}

$25 \mathrm{~mm}$ trap opening. Following Obaza et al. (2011), we treated catch-per-minnow-trap as a measure of encounter rate.

We sampled four sites within long-hydroperiod areas (hydroperiod $>300$ days per year inundated) and five shorthydroperiod sites ( $<300$ days inundated; Trexler et al., 2001). Each site had multiple traps less than one $\mathrm{km}$ apart (Table 1). Sampling began in May 2004 and continued through December 2009. We attempted to sample monthly in the long-hydroperiod areas and as often as twice a month in the short-hydroperiod sites when water was present; access and low water levels limited sampling in the dry season. Traps were soaked for 24 hours, after which, fishes were removed. Fishes were euthanized by immersion in a solution of tricaine methane sulfonate (MS-222; Argent Chemical Laboratories, Inc., Redmond, WA), followed by preservation in a $10 \%$ formalin solution (UFR Committee, 2004). In the laboratory, fishes were transferred to $70 \%$ ethanol, identified to species, and counted.

Fish population density estimates were obtained for a subset of our samples (within the same month as sampling) by means of throw-trap sampling. Throw trapping was not possible at our short-hydroperiod sites because of rocky and uneven substrate, so to estimate fish population density in short-hydroperiod conditions, we used data collected in nearby areas. We collected density data in areas between 5 and $10 \mathrm{~km}$ from short-hydroperiod sites ("Short- $A^{\text {") }}$ and between 1 and $5 \mathrm{~km}$ from other short-hydroperiod sites ("Short-B"). A $1 \mathrm{~m}^{2}$ throw trap with $1.6 \mathrm{~mm}$ mesh covering four sides was thrown into random positions within a plot and quickly pressed into the substrate. Fishes were collected by passing a bar seine ( $1.6 \mathrm{~mm}$ mesh) through the trap until three consecutive passes of the bar seine yielded no animals. After the trap was cleared with the bar seine, dip nets $(0.5$ and $1.5 \mathrm{~mm}$ mesh) were passed through it until five consecutive passes yielded no fish (see Jordan et al., 1997 for complete methodology). Three to seven throw-trap samples were taken at each site in the long-hydroperiod sites (following Jordan et al., 1997). We used the throw-trap data to calculate the average density per square-meter for the most common species.

For sites where fish movement was estimated using drift fences and densities were estimated with throw traps (sites 6 , $7,8,23$, and 50), fish speed was calculated following Obaza et al. (2011). Encounter rate of mobile prey, $E$ (treating the 
minnow trap as a stationary predator), can be estimated by (simplified from Gerritson and Strickler, 1977; MacKenzie and Kiorboe, 1995):

$$
E=V N+\mu A N
$$

We solved for $\mu$, the speed of the prey. $A$ is the search area and $V$ is volume searched per unit time (both constants across this study because traps were all the same size and soaked for the same length of time). $N$ is the density of fish. Therefore, fish speed is proportional to the relative difference between the encounter rate and population density $(\mu \propto[E-N] / N)$. We have found that this approach yields reasonable estimates of movement speed $(\mathrm{m} / \mathrm{sec})$ based on independent estimates from the literature (Obaza et al., 2011), but we use these values as an index of relative speed.

Encounter rate, $E$, was calculated as the average number of fish caught in directional minnow traps at a replicate drift fence within a site. Bias in directional movement was calculated by considering catch in a single minnow trap as a vector in the direction that it faces and a magnitude equal to the number of fish caught within it. We averaged the vectors from the four directions of the minnow traps within a drift fence using the Pythagorean Theorem (Fig. 2).

We did not analyze the specific direction of the vector because it may be influenced by factors that were not measured, like the direction of paths to long-hydroperiod sites (owing to sawgrass ridges [Larsen and Harvey, 2010]), direction to local refuges (canals and alligator ponds), regional-scale impediments to travel (levees and tree islands), specific environmental gradients (for example, food availability), or forward persistence propensity by individuals (Benhamou, 2006). Instead, we focused on the magnitude of the bias-vector because it represents fish moving together in the same direction, possibly in large pulses (Goss et al., 2013), and identified non-random directional movement, if present. We distinguished between directed movement and random movement of fish moving in large schools by using the average magnitude of directional bias collected from multiple replicate traps at a single site at the same time.

We interpret a lack of variation in encounter rate or directional bias between hydroperiod regions or seasons (rising, stable, or falling water) as indicative of fishes not changing behaviors in response to the changing environment. If the encounter rate of fishes vary between short- and long-hydroperiod regions and among periods of the year, but directional bias does not, we interpret this as indicative of changing activity in response to environmental cues but with non-directed, essentially random, travel. Finally, we interpret differences in encounter rates and directional bias between hydroperiod regions or during periods of changing water levels as fishes changing activity levels and increasing the directional bias of their movements. Directed movements that peak as water levels increase are interpreted as "exploratory" movement by those fish (Burns, 2004). Those that peak as water levels began to fall are interpreted as "escape" behaviors. During periods of falling water, an increase in activity without an increase in directional bias is interpreted as "panicking."

Statistical analysis. - We performed all analyses separately for the eight most abundant fishes captured in our study. We explored variation in fish population density by comparing the estimates from throw-trap samples from seven long-term study sites (Fig. 1). Sites 23, 6, 7, and 8 were pooled into "long-hydroperiod," and collections from Short-A, Short-B, and 50 were grouped into "short-hydroperiod." We only used samples that were collected during the wet season (May-December) because during the dry season, too many short-hydroperiod sites were dry (Table 1). For each species, we used a general linear model to perform factorial analysis of variance (SAS 9.2, SAS Institute, 2008) to determine the effect of site (nested within region), region, year, and the interaction between region and year on variation in wetseason population density $(\log [x+1]$ transformed for all data to meet standard assumptions). Year was treated as a random factor to account for inter-annual variation affecting all sites similarly.

We were concerned that drift-fence catch might reflect local population density rather than movement of fish over the landscape. To test whether this was the case, we performed model II regression (orthogonal, univariate variances; JMP 5.1, SAS Institute, 2005), using drift-fence catch to predict density as indicated by throw traps. We used only data where neither encounter rate nor density were zero, and performed log-transformations for all density and encounter rates to meet standard statistical assumptions. We compared the calculated speed $(\mu)$ of fish for the sites where we had both throw-trapping density estimates and driftfence encounter rate estimates (sites 6, 7, 8, 23, and 50) with a general linear model ANOVA (SAS Institute, 2008). When the effect of site was significant $(P<0.05)$, we used TukeyKramer post-hoc tests to determine which sites differed from each other.

To test our hypotheses about movement behavior, we used non-parametric (rank transformed), factorial ANOVA (SAS Institute, 2008) to identify how encounter rates varied among seasons and between hydroperiod regions for each species. We tested the hypotheses that encounter rate was equal in long- and short-hydroperiod regions, among periods of rising, falling, or stable water, and with their interactions. The "wet season" typically begins in May or June when water levels rise and short-hydroperiod marshes re-flood. During the late summer and early fall water levels are approximately stable. Water levels begin to drop in the late fall, and short-hydroperiod wetlands can be completely dry by the end of December (but occasionally are wet until later in the winter). Water levels were retrieved from the Everglades Depth Estimate Network (an integrated network of real-time water-level monitoring, and ground-level/watersurface modeling; Liu et al., 2009; Telis et al., 2012). Sites 6, 7,8 , and 23 were treated as long-hydroperiod sites, and S332B, S332D, Chekika, Context Road, and 50 as shorthydroperiod sites (Fig. 1). We completed similar nonparametric (rank transformed), factorial (SAS Institute, 2008) ANOVAs for the magnitude of directional bias, but only included samples with the species of interest present.

\section{RESULTS}

The most common fishes captured by drift fences were Marsh Killifish (Fundulus confluentus; $n=1302$, standard lengths [SL] of these fish ranged from $15 \mathrm{~mm}$ to $70.6 \mathrm{~mm}$ ), Eastern Mosquitofish $(n=21502$, SL range $5.6-52.6 \mathrm{~mm})$, Flagfish $(n=3624$, SL range 8.3-41.5 mm), Dollar Sunfish (Lepomis marginatus, $n=6970$, SL range $12.3-58.5 \mathrm{~mm}$ ), Bluefin Killifish (Lucania goodei, $n=1547$, SL range $5.3-36.5 \mathrm{~mm}$ ), and Sailfin Molly (Poecilia latipinna, $n=$ 2038, SL range 8.60-59.1 mm). We also analyzed data for 
Table 2. ANOVA table for comparison of throw-trap data in the wet-season samples of our collection period. $R^{2}$ value refers to the coefficient of determination for the general linear model used to perform the tests.

\begin{tabular}{|c|c|c|c|c|c|}
\hline Species $\left(R^{2}\right)$ & Factors & $\mathrm{df}$ & MS & $F$ & $P$ \\
\hline Golden Topminnow & Site(region) & 10 & 0.0609 & 2.81 & 0.0045 \\
\hline \multirow[t]{3}{*}{-0.4459} & Region & 1 & 0.2553 & 11.8 & 0.0009 \\
\hline & Year & 5 & 0.0097 & 0.45 & 0.8128 \\
\hline & Year*region & 5 & 0.0392 & 1.81 & 0.1183 \\
\hline Marsh Killifish & Site(region) & 10 & 0.0414 & 5.22 & $<0.0001$ \\
\hline \multirow[t]{3}{*}{-0.4595} & Region & 1 & 0.0213 & 2.69 & 0.1045 \\
\hline & Year & 5 & 0.0069 & 0.87 & 0.5021 \\
\hline & Year*region & 5 & 0.0064 & 0.81 & 0.5479 \\
\hline Eastern Mosquitofish & Site(region) & 10 & 0.2609 & 1.98 & 0.0452 \\
\hline \multirow[t]{3}{*}{-0.4073} & Region & 1 & 0.1208 & 0.92 & 0.3412 \\
\hline & Year & 5 & 0.3824 & 2.9 & 0.0181 \\
\hline & Year*region & 5 & 0.6121 & 4.64 & 0.0008 \\
\hline Least Killifish & Site(region) & 10 & 0.2158 & 4.6 & $<0.0001$ \\
\hline \multirow[t]{3}{*}{-0.6465} & Region & 1 & 1.175 & 25.05 & $<0.0001$ \\
\hline & Year & 5 & 0.2254 & 4.81 & 0.0006 \\
\hline & Year*region & 5 & 0.1444 & 3.08 & 0.0132 \\
\hline Flagfish & Site(region) & 10 & 0.1276 & 1.87 & 0.0594 \\
\hline \multirow[t]{3}{*}{-0.3005} & Region & 1 & 0.1115 & 1.64 & 0.2038 \\
\hline & Year & 5 & 0.1495 & 2.2 & 0.0617 \\
\hline & Year*region & 5 & 0.0427 & 0.63 & 0.6793 \\
\hline Dollar Sunfish & Site(region) & 10 & 0.0039 & 2.86 & 0.0039 \\
\hline \multirow[t]{3}{*}{-0.3542} & Region & 1 & 0.0039 & 2.83 & 0.0959 \\
\hline & Year & 5 & 0.0026 & 1.88 & 0.1055 \\
\hline & Year*region & 5 & 0.0022 & 1.61 & 0.166 \\
\hline Bluefin Killifish & Site(region) & 10 & 0.8469 & 17.78 & $<0.0001$ \\
\hline \multirow[t]{3}{*}{-0.7734} & Region & 1 & 1.7549 & 36.83 & $<0.0001$ \\
\hline & Year & 5 & 0.1034 & 2.17 & 0.0645 \\
\hline & Year*region & 5 & 0.0852 & 1.79 & 0.1235 \\
\hline Sailfin Molly & Site(region) & 10 & 0.0099 & 1.2 & 0.3025 \\
\hline \multirow[t]{3}{*}{-0.2395} & Region & 1 & 0.0013 & 0.15 & 0.6968 \\
\hline & Year & 5 & 0.0207 & 2.5 & 0.0367 \\
\hline & Year*region & 5 & 0.0033 & 0.4 & 0.848 \\
\hline
\end{tabular}

Golden Topminnow (Fundulus chrysotus, $n=470$, SL range 14.1-67.8 $\mathrm{mm}$ ) and Least Killifish (Heterandria formosa, $n=$ 247 , SL range 12.24-34.9 $\mathrm{mm}$ ). Individuals of small sizes may have been able to escape through the mesh of the traps and similarly, large individuals of deeper bodied fish, like Dollar Sunfish, may not have been able to fit in. Only three of the species that we evaluated exhibited differences in density between long- and short-hydroperiod areas: Golden Topminnow, Least Killifish, and Bluefin Killifish were 2.3, 4.2 , and 8.2 times denser at long-hydroperiod sites than at short-hydroperiod sites, respectively (Fig. 3A, 3B; Table 2).

Only two species exhibited relationships between encounter rate and population density. Encounter rates $(E)$ of Flagfish were positively related to population density (but with a low coefficient of determination; slope $=1.26, \mathrm{R}^{2}=$ $0.18, P=0.027$; Fig. 4), while encounter rates of Bluefin Killifish were negatively related to their density (slope $=$ $-1.016, \mathrm{R}^{2}=0.082, P=0.040$; Fig. 4). Since drift-fence encounter rate is proportional to the product of fish speed and their density in the study area (Obaza et al., 2011), but density is not strongly correlated with encounter rate, we interpret variation in encounter rate as more indicative of variation in fish activity than local population density.

Estimated speed $(\mu)$ varied among sites for Eastern Mosquitofish $\left(F_{4,96}=4.12, P=0.004\right)$ and Least Killifish $\left(F_{4,14}=18.97, P=0.0002\right)$. Post-hoc tests showed that
Eastern Mosquitofish moved fastest at site 50 (a shorthydroperiod site) and slowest at sites 6, 7, and 8 (longhydroperiod sites). Site 23 (long-hydroperiod site) was intermediate and not detectably different from other sites. Least Killifish moved faster at site 50 than at any other site. Bluefin Killifish showed variation in speed among sites $\left(F_{4,52}\right.$ $=2.6, P=0.0482$ ), but post-hoc tests could not identify any particular sites as having faster-moving fish.

All of the fishes showed at least some behavioral response to either the hydroperiod of the wetland or whether water was rising, stable, or falling (Fig. 3A, 3B; Tables 3-5). Two species showed variation in activity levels (as indicated by differences in encounter rate), but not directional bias (Tables 3, 4). Sailfin Mollies displayed increased activity during periods of rising and falling water level (Fig. 3B). Least Killifish displayed greater encounter rates as water levels increased in short-hydroperiod regions (Fig. 3A). Directional bias did not vary for Sailfin Mollies or Least Killifish. Four species displayed directionally biased movement: Eastern Mosquitofish, Dollar Sunfish, Flagfish, and Bluefin Killifish (Fig. 3A, 3B; Table 4). Of these, Eastern Mosquitofish was most notable, with greater encounter rates and directional bias as water levels dropped and at shorthydroperiod sites (encounter rate also varied with the interaction between season and region; Fig. 3A). Dollar Sunfish had greater encounter rates and directional bias as 
A Golden Topminnow
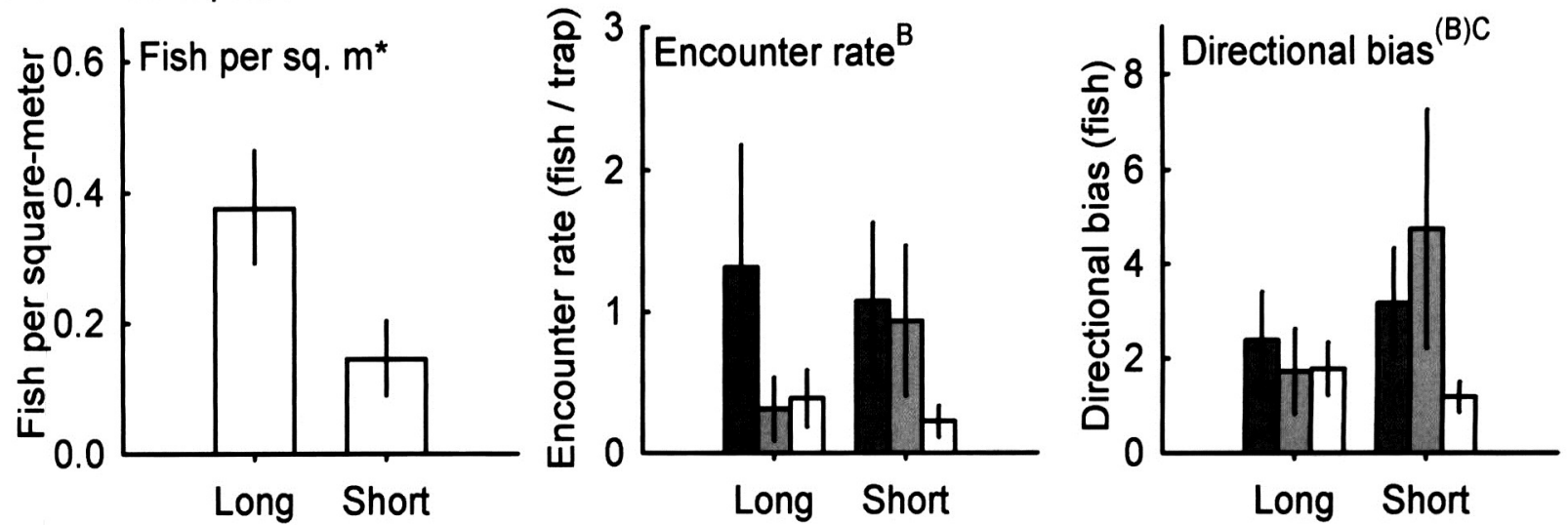

B Marsh Killifish
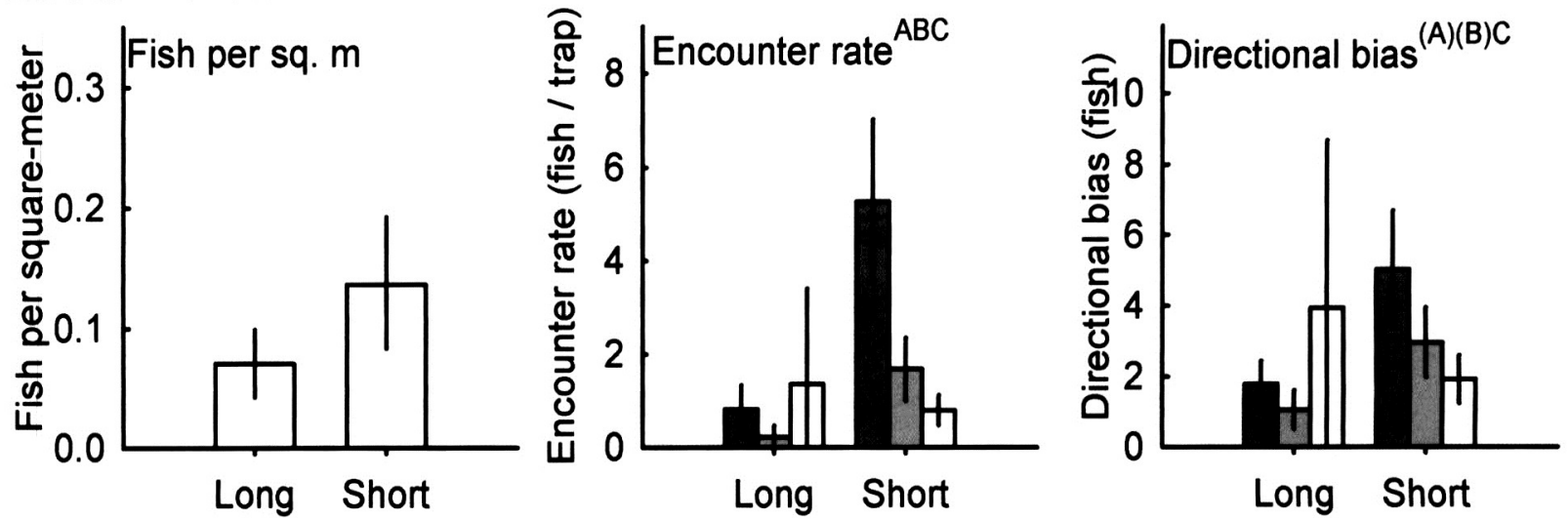

C Eastern Mosquitofish
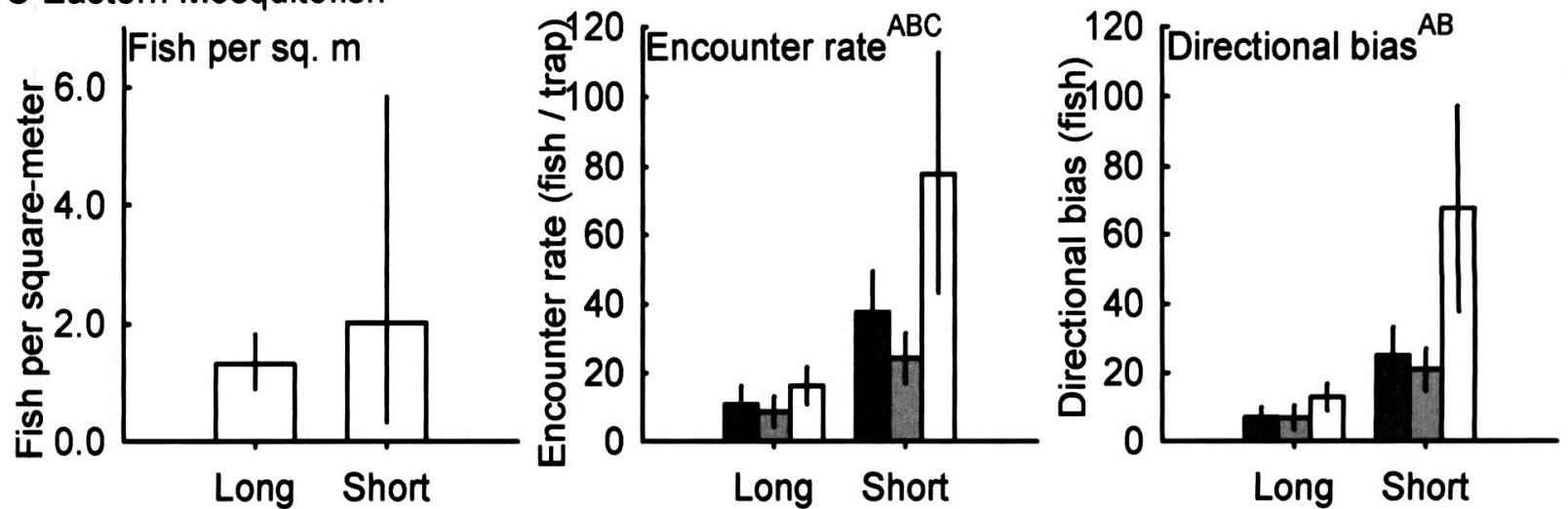

D Least Killifish
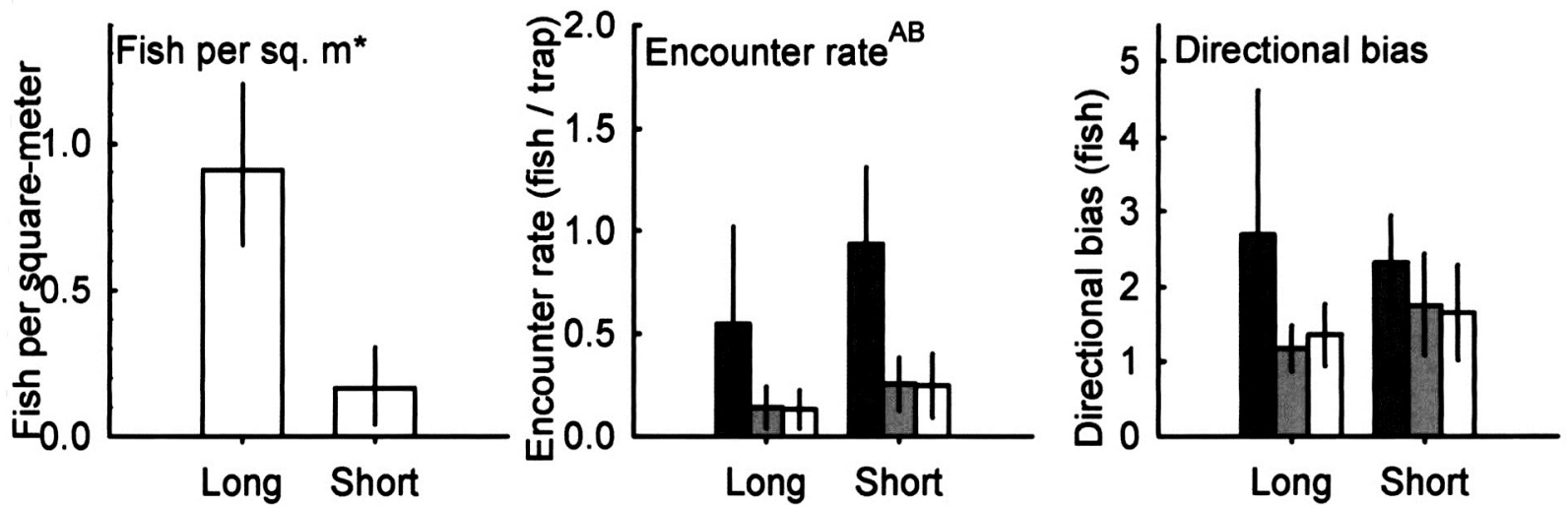

Fig. 3. A-D (this page) and E-H (following page): Averaged data of the eight fish species from this study. The first column shows population density (back-transformed), measured by throw trapping concurrently with drift-fence sampling. Graphs marked with an asterisk have significant differences between hydroperiod regions at $P<0.05$. The second and third columns show mean encounter rates and bias in directional movement (magnitude of the bias vector), respectively. Each of these shows drift fences within regions of long- and short-hydroperiod, for periods of rising water (dark gray), stable water (medium gray), and falling water (light gray). Error bars show 95\% Cl. Species superscripted with an " $A$ " had significant differences between hydroperiod regions at $P<0.05$; those with " $B$ " had a significant difference among periods of water change; those with " $C$ " had significant interactions between region and water level change. Letters in parentheses indicate that the differences were not significant, but nearly so $(0.05<P<0.10)$. 


\section{E Flagfish}

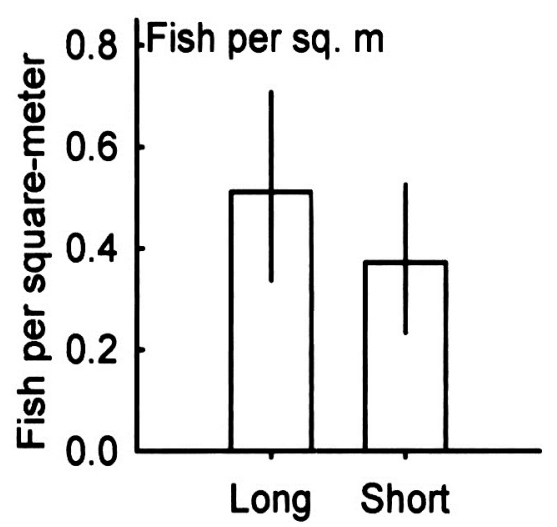

F Dollar Sunfish

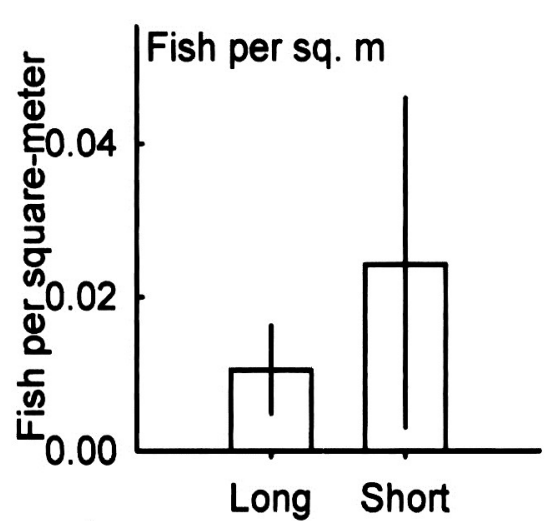

G Bluefin Killifish
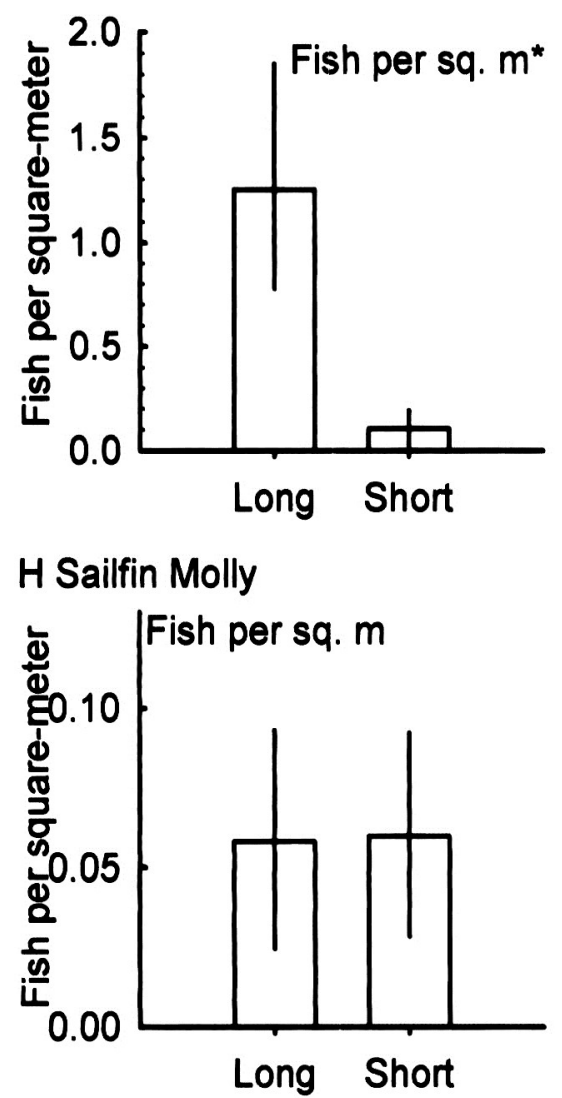
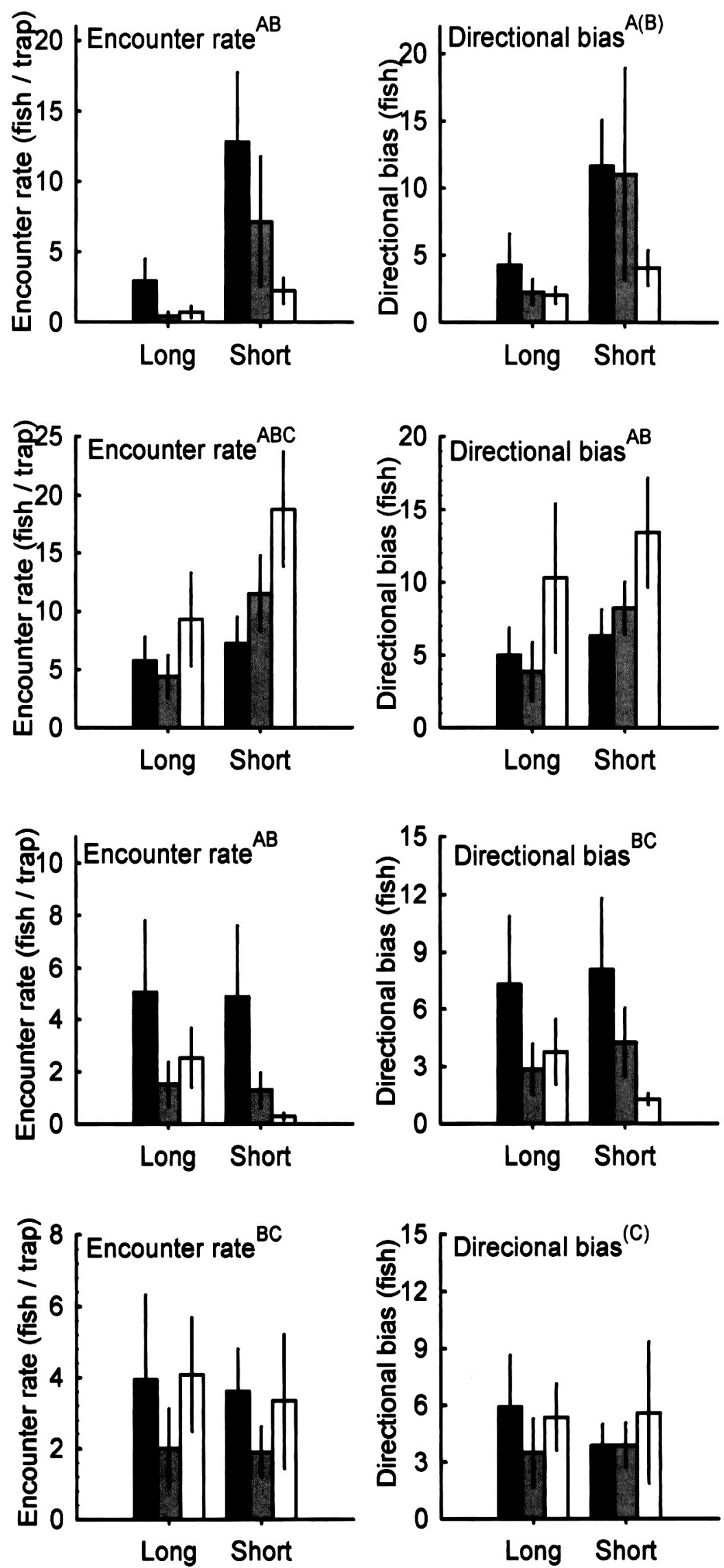

Fls. 3. Continued. 

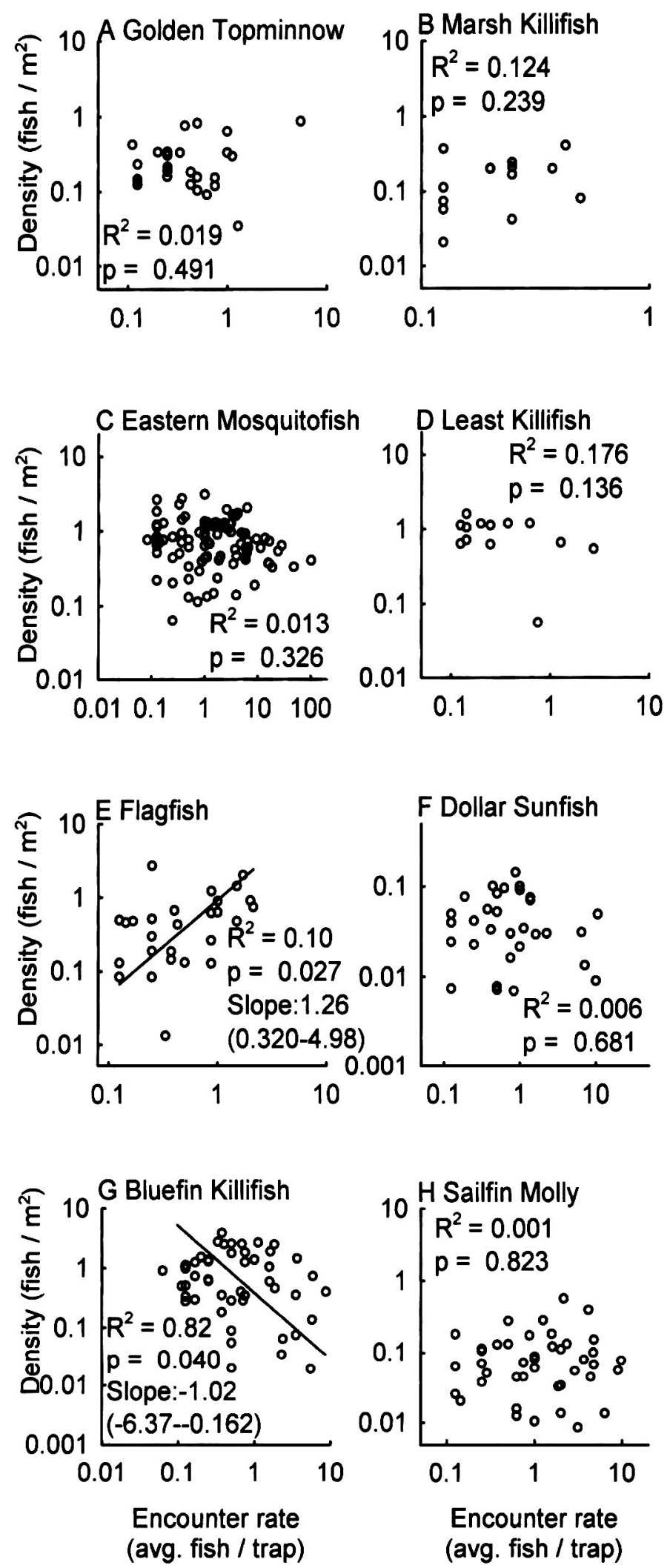

Fig. 4. Population density plotted against encounter rate for eight fish species. Best-fit lines from model II regression appear in the graphs when the regression had $P<0.05$, with the slope and its $95 \%$ confidence interval (in parentheses).

water levels rose and in short-hydroperiod sites. Encounter rates of Flagfish were greatest as water levels rose and at short-hydroperiod sites; their directional bias was greatest in short-hydroperiod sites. Bluefin Killifish had greatest encounter rates in the long-hydroperiod sites and during periods of rising water; their directional bias was also greatest as water rose and varied with the interaction between region and season. Two species appeared to alter their levels of directional bias only when faced with specific combinations of water-level change and region. Golden Topminnows and Marsh Killifish both displayed variable encounter rates and directional bias that varied with the interaction between region and season. We have summarized these results in Table 5.

\section{DISCUSSION}

The diversity of migratory behaviors represented in a community can have major consequences for community assembly following disturbance events (Wissinger, 1997; Elkin and Possingham, 2008; Altermatt et al., 2011). We have not found other studies that have attempted to systematically characterize migration behavior by multiple members of a community. By using local population density, encounter rate, and directional bias as metrics to characterize fish movement, we found interspecific differences in movement behavior among periods of changing water level and between hydroperiod regions for six of the eight species in this study. Data for all fish species led to rejection of the null hypothesis of random diffusive movement. We found that six of the eight most abundant small fishes in the Everglades displayed directed migration associated with periods of changing water level. Two species were best characterized as dispersing over the landscape via diffusion with two general activity modes: "baseline" and "elevated."

The increased speed and magnitude of fish moving in the same direction is evidence for directed migration over the landscape between short- and long-hydroperiod wetlands or dry-season refuges. This pattern is consistent with animals moving with taxis along environmental gradients, presumably to elevate their fitness (Schick et al., 2008; DeAngelis et al., 2010), and allows the fish to move rapidly into newly available habitats and flee degrading environments. Often, these fish appeared to move together in large pulses. For example, as the habitats dry in the early winter in shorthydroperiod wetlands, we regularly captured hundreds of Eastern Mosquitofish in a single trap. This is consistent with work completed over a smaller geographic range, but greater temporal intensity, in which three behavioral patterns were identified for four of the same fishes that this study addresses (Eastern Mosquitofish, Flagfish, Least Killifish, and Bluefin Killifish): immigration to a short-hydroperiod wetland, a period of low activity "foraging," followed by emigration (Goss et al., 2013). When scaled up to landscape level migrations, species-specific migratory behavior can have implications for population displacement and community assembly by affecting the timing and probability that species arrive in safe habitats.

When drift fences were used concurrently with throw trapping, we were able to detect differences in speed $(\mu)$ among sites for Eastern Mosquitofish, Least Killifish, and Bluefin Killifish. For Least Killifish and Eastern Mosquitofish, site 50 had fishes that moved most quickly, followed by site 23 (Bluefin Killifish also varied for speed, but post-hoc tests were unable to identify any specific pairs of sites as different from each other). This is consistent with the hypothesis that the fishes that immigrate into shorthydroperiod regions, like site 50 , do so because of behavioral changes that increase their speed. None of the species had greater wet-season population densities in short-hydroperiod regions (four were equal between hydroperiod regions, 
Table 3. Results from non-parametric factorial ANOVA for encounter rate for each species.

\begin{tabular}{|c|c|c|c|c|c|}
\hline Species & Factors & df & MS & $F$ & $P$ \\
\hline \multirow[t]{3}{*}{ Golden Topminnow } & Region & 1 & 8120 & 0.49 & 0.4849 \\
\hline & Season & 2 & 97300 & 5.86 & 0.003 \\
\hline & Region*season & 2 & 8230 & 0.5 & 0.6096 \\
\hline \multirow[t]{3}{*}{ Marsh Killifish } & Region & 1 & 1200000 & 54.81 & $<0.0001$ \\
\hline & Season & 2 & 383000 & 17.47 & $<0.0001$ \\
\hline & Region*season & 2 & 89400 & 4.07 & 0.0175 \\
\hline \multirow[t]{3}{*}{ Eastern Mosquitofish } & Region & 1 & 476000 & 14.27 & 0.0002 \\
\hline & Season & 2 & 290000 & 8.68 & 0.0002 \\
\hline & Region*season & 2 & 135000 & 4.05 & 0.0179 \\
\hline \multirow[t]{3}{*}{ Least Killifish } & Region & 1 & 81200 & 5.8 & 0.0163 \\
\hline & Season & 2 & 86200 & 6.15 & 0.0022 \\
\hline & Region*season & 2 & 19100 & 1.36 & 0.2569 \\
\hline \multirow[t]{3}{*}{ Flagfish } & Region & 1 & 716000 & 28.01 & $<0.0001$ \\
\hline & Season & 2 & 394000 & 15.42 & $<0.0001$ \\
\hline & Region*season & 2 & 47400 & 1.85 & 0.1574 \\
\hline \multirow{3}{*}{ Dollar Sunfish } & Region & 1 & 469000 & 13.97 & 0.0002 \\
\hline & Season & 2 & 129000 & 3.85 & 0.0218 \\
\hline & Region*season & 2 & 134000 & 3.99 & 0.0189 \\
\hline \multirow[t]{3}{*}{ Bluefin Killifish } & Region & 1 & 742000 & 32.19 & $<0.0001$ \\
\hline & Season & 2 & 124000 & 5.37 & 0.0049 \\
\hline & Region*season & 2 & 50500 & 2.19 & 0.1128 \\
\hline \multirow[t]{3}{*}{ Sailfin Molly } & Region & 1 & 11100 & 0.4 & 0.526 \\
\hline & Season & 2 & 144000 & 5.22 & 0.0056 \\
\hline & Region*season & 2 & 166000 & 5.99 & 0.0026 \\
\hline
\end{tabular}

four were denser in long-hydroperiod sites), yet all of the fishes (except Sailfin Mollies and Bluefin Killifish) had equal or greater encounter rates at short-hydroperiod sites. This suggests that those species move more quickly at short- hydroperiod sites. Given the population densities and encounter rates of Bluefin Killifish and Sailfin Mollies in the long- and short-hydroperiod regions, both appear to maintain similar movement speeds in both regions.

Table 4. Results for non-parametric factorial ANOVA for bias in directional movement for each species.

\begin{tabular}{|c|c|c|c|c|c|}
\hline Species & Factors & $\mathrm{df}$ & MS & $F$ & $P$ \\
\hline \multirow[t]{3}{*}{ Golden Topminnow } & Region & 1 & 289 & 0.26 & 0.6083 \\
\hline & Season & 2 & 3030 & 2.76 & 0.0671 \\
\hline & Region*season & 2 & 3500 & 3.19 & 0.0447 \\
\hline \multirow[t]{3}{*}{ Marsh Killifish } & Region & 1 & 13400 & 3.88 & 0.0501 \\
\hline & Season & 2 & 8660 & 2.51 & 0.084 \\
\hline & Region*season & 2 & 13600 & 3.93 & 0.021 \\
\hline \multirow[t]{3}{*}{ Eastern Mosquitofish } & Region & 1 & 497000 & 25.83 & $<0.0001$ \\
\hline & Season & 2 & 150000 & 7.8 & 0.0005 \\
\hline & Region*season & 2 & 28000 & 1.45 & 0.2348 \\
\hline \multirow[t]{3}{*}{ Least Killifish } & Region & 1 & 397 & 0.57 & 0.4514 \\
\hline & Season & 2 & 1430 & 2.06 & 0.1326 \\
\hline & Region*season & 2 & 30.7 & 0.04 & 0.9568 \\
\hline \multirow[t]{3}{*}{ Flagfish } & Region & 1 & 67200 & 13.07 & 0.0004 \\
\hline & Season & 2 & 15000 & 2.92 & 0.0557 \\
\hline & Region*season & 2 & 3210 & 0.62 & 0.5367 \\
\hline \multirow[t]{3}{*}{ Dollar Sunfish } & Region & 1 & 306000 & 17.55 & $<0.0001$ \\
\hline & Season & 2 & 100000 & 5.73 & 0.0035 \\
\hline & Region*season & 2 & 40400 & 2.31 & 0.1001 \\
\hline \multirow[t]{3}{*}{ Bluefin Killifish } & Region & 1 & 1730 & 0.52 & 0.4716 \\
\hline & Season & 2 & 28300 & 8.51 & 0.0003 \\
\hline & Region*season & 2 & 16700 & 5 & 0.0076 \\
\hline \multirow{3}{*}{ Sailfin Molly } & Region & 1 & 10000 & 1.64 & 0.2017 \\
\hline & Season & 2 & 5680 & 0.93 & 0.3963 \\
\hline & Region*season & 2 & 15100 & 2.47 & 0.0869 \\
\hline
\end{tabular}


Table 5. Summary of behavioral patterns and hydrological conditions at maximum activity/movement for each species. Directed movers increased directional bias given a hydrological cue. Composite diffusers displayed variation in activity but not directional bias. No fish showed evidence for simple diffusion (random movement). "Exploring" fish had their maximum activity and directedness as water levels rose, "escaping" fish had maximum activity and directedness as water levels fell, "strongly migratory" fish had directed movement at either period of water level change, and "panicking" fish had higher, but undirected, activity at periods of water level change.

\begin{tabular}{lll}
\hline Species & \multicolumn{1}{c}{ Behavioral pattern } & \multicolumn{1}{c}{ Hydrological conditions } \\
\hline Golden Topminnow & Directed movement, exploring & Rising water \\
Marsh Killifish & Directed movement, exploring & Rising water, especially at short-hydroperiod sites \\
Eastern Mosquitofish & Directed movement, strongly migratory & Rising or falling water, esp. at short-hydroperiod sites \\
Least Killifish & Composite diffusion & Rising water, especially at short-hydroperiod sites \\
Flagfish & Directed movement, exploring & Rising water, especially at short-hydroperiod sites \\
Dollar Sunfish & Directed movement, escaping & Falling water, especially at short-hydroperiod sites \\
Bluefin Killifish & Directed movement, anti-migratory & Rising water, especially at long-hydroperiod sites \\
Sailfin Molly & Composite diffusion, panicking & Changing water level
\end{tabular}

The most abundant species, Eastern Mosquitofish, was a strongly directed mover (Table 5), with greater encounter rates and directional bias in short-hydroperiod regions and higher activity during the periods of changing water level. Eastern Mosquitofish movement patterns suggest they are following a dynamic ideal free distribution. Eastern Mosquitofish are widely reported to be very rapid colonizers of new habitats and efficient emigrants from degrading habitats (Brown, 1985, 1987; Loftus and Kushlan, 1987; Trexler et al., 2001, 2005; Ruetz et al., 2005; Goss et al., 2013). We believe that these migrations are driven by following fitness gradients, perhaps toward high levels of food made available as dry wetlands become flooded and then escaping those areas as they dry (although we did not directly measure fitness over the landscape). The diversity and density of small invertebrates (a major food source for the fishes in this study) are greater in shorter hydroperiod regions (Sokol et al., 2013), suggesting that perhaps food availability is a motivation for fish to move in to the temporary wetlands. Directionality was more pronounced in the short-hydroperiod regions, where fitness gradients are likely steeper. The relationship between the population density of Eastern Mosquitofish and a site's hydrology has been reported to be weak (Trexler et al., 2001; Ruetz et al., 2005; Trexler and Goss, 2009). This is probably because they are extremely fast colonizers of newly available habitat and may follow very closely behind the flooding front of water as it arrives in reflooded areas (Brown, 1985, 1987; Loftus and Kushlan, 1987; Trexler et al., 2001, 2005; Ruetz et al., 2005). They have also been reported to be the last to emigrate from drying marshes and do so over a short period of time just prior to complete drying (Cucherousset et al., 2007).

Flagfish and Marsh Killifish attain their maximum population densities very soon after marsh re-flooding, followed by a steady reduction in densities (Trexler et al., 2001, 2005; Ruetz et al., 2005; Trexler and Goss, 2009). Our results are consistent with these fishes, along with Golden Topminnow, rapidly entering a newly flooded, shorthydroperiod site owing to increased activity and directional bias, then reducing activity as the wet season continues. This may reflect an "exploratory" behavior mode used by these fishes, increasing their likelihood of entering newly opened, high quality habitat (Table 5). A striking pattern for Marsh Killifish was the region-by-season interaction for both activity levels and directional bias. Marsh Killifish had a very high encounter rate and directional bias as water rose at short-hydroperiod sites. In the long-hydroperiod sites, movement direction was most biased when water levels were falling. This is also consistent with the elimination of a food-availability gradient between long- and short-hydroperiod sites as prey is progressively grazed down. Dollar Sunfish increase directional bias and activity levels as water levels drop, suggesting that they switch to an "escaping" behavioral mode in order to emigrate from a region before it dries.

Bluefin Killifish populations are reported to enter areas recovering from drying very slowly, sometimes taking years to reach pre-drying densities in places that only dry rarely (Trexler et al., 2001; DeAngelis et al., 2005; Ruetz et al., 2005; Trexler and Goss, 2009). Because Bluefin Killifish did show bias in directional movement, but remained scarce in short-hydroperiod sites, it is likely that the cues that they follow are not oriented in the direction of the hydroperiod gradient (displaying "anti-migratory" behaviors; Table 5). They may be discouraged from entering newly flooded habitats by predators or competitors that move in quickly. In that case, Bluefin Killifish would be unlikely to rapidly colonize newly flooded areas and instead arrive slowly.

Sailfin Mollies and Least Killifish appeared to increase activity levels in different hydroperiod regions or seasons, but without using directional bias. These species may increase movement speeds or step lengths in response to cues, but they do not appear to navigate in an organized way. This may be similar to behaviors observed for elk: switching between "encamped" behaviors when conditions are good, to "exploratory" behaviors when conditions deteriorate (Morales et al., 2004). This also may be an example of fish taking paths similar to Lévy walks, with a series of longer step lengths to increase efficiency in diffusing through the environment (Benhamou, 2007). Such dispersers move over the landscape following a reactiondiffusion pattern and, owing to increased sampling of the environment, may locate favorable habitats, but at a lower rate than the directed movers. The movement behaviors of the Least Killifish may result in an apparent ideal free distribution because once favorable habitats are reached, fish may remain. The Sailfin Molly's increase in movement rates as water levels drop may correspond to "panicking" behavior during its last opportunity to seek dry-season refuge (Table 5).

Differential dispersal ability and behavior can greatly affect community structure and metacommunity dynamics (Leibold et al., 2004; Elkin and Possingham, 2008; Altermatt et al., 2011). Because of different dispersal strategies used by 
different fishes, community structure at short-hydroperiod sites is likely to be quite dynamic. Superior dispersers should be the first to exploit newly available wetlands upon flooding, followed by those with progressively slower colonization behaviors. Some members of the community may not arrive before conditions change again, and thus be underrepresented in some parts of the landscape. In most years, by the end of the summer, fish community structure in short-hydroperiod regions is similar to that of longhydroperiod sites (Sokol et al., 2013). This demonstrates that despite the differences in movement among species, the community is capable of successfully regenerating. During the dry season, Everglades fishes may become concentrated into drying pools where they are preyed upon by large assemblages of wading birds (Frederick et al., 2009). We predict that those assemblages may be biased toward fishes that are the slowest to emigrate in periods of drought. In years with less rainfall, the hydroperiod of temporary wetlands may be severely reduced. During these years, species that are poorer dispersers (Sailfin Mollies and Bluefin Killifish, for example) may be less able to migrate to these sites (or not appear at all), thus altering the local food web.

We have demonstrated that movement behavior changes over time and space for small fishes using passive sampling methods. For these abundant fishes in the Everglades, we have shown that random migrations are unlikely; fishes respond to changing conditions by increasing activity levels, by increasing the magnitude of bias in their directional movement, or both. Those behaviors can be used to predict how and when species will enter newly available habitat to escape disturbances. These empirical results support the models published by DeAngelis et al. (2010), which predict that fishes move non-randomly toward short-hydroperiod wetlands as they re-flood each year. Movement behaviors reported here also support the hypothesis of Goss et al. (2013), that fishes adjust behavior in response to the hydrological state of their environment. These results have immediate application in ongoing restoration of the Everglades through application in modeling efforts used to guide planning (Jopp et al., 2010; Yurek et al., 2013). We propose that community-wide description of movement behavior can be used to better understand successional dynamics in disturbed ecosystems, parameterize models of animal migration across landscapes, and improve our understanding of metacommunities.

\section{ACKNOWLEDGMENTS}

This paper would not have been possible without intellectual and practical input from J. Kline, A. Obaza, J. Parkos, C. Catano, and the crew of the Trexler Laboratory at FIU. We particularly wish to thank W. Loftus for helping to design drift fences as a tool to enhance capture of fish in shorthydroperiod wetlands. W. Loftus, D. DeAngelis, and S. Yurek all provided valuable comments on early drafts of this manuscript. Financial support for this project. was provided by Cooperative Agreement H5000060104, Task No. J5284060023 from Everglades National Park and agreement 4600001083 from South Florida Water Management District to Florida International University. This material was developed in collaboration with the Florida Coastal Everglades Long-Term Ecological Research program under $\mathrm{Na}$ tional Science Foundation Grant No. DEB-9910514. Collections were made under Everglades National Park permit EVER-2010-SCI-0058 and Florida State permit S-11-04. This research was conducted in accordance with FIU IACUC (Protocol number 06-015). Specimens and data are housed at Florida International University, Biscayne Bay Campus (3000 NE 151st St, North Miami, FL 33181). This is Contribution number 675 from the Southeast Environmental Research Center at Florida International University.

\section{LITERATURE CITED}

Abrams, P. A., R. Cressman, and V, Křivan. 2007. The role of behavioral dynamics in determining the patch distributions of interacting species. The American Naturalist 169:505-518.

Altermatt, F., S. Schreiber, and M. Holyoak. 2011. Interactive effects of disturbance and dispersal directionality on species richness and composition in metacommunities. Ecology 92:859-870.

Armsworth, P. R., and J. E. Roughgarden. 2005. The impact of directed versus random movement on population dynamics and biodiversity patterns. The American Naturalist 165:449-465.

Baber, M. J., D. L. Childers, K. J. Babbitt, and D. H. Anderson. 2002. Controls on fish distribution and abundance in temporary wetlands. Canadian Journal of Fisheries and Aquatic Science 59:1441-1450.

Benhamou, S. 2006. Detecting an orientation component in animal paths when the preferred direction is individual-dependent. Ecology 87:518-528.

Benhamou, S. 2007. How many animals really do the Lévy walk? Ecology 88:1962-1969.

Brown, K. L. 1985. Demographic and genetic characteristics of dispersal in the mosquitofish, Gambusia affinis (Pisces: Poeciliidae). Copeia 1985:597-612.

Brown, K. L. 1987. Colonization by Mosquitofish (Gambusia affinis) of a Great Plains River Basin. Copeia 1987: 336-351.

Burns, J. G. 2004. The validity of three tests of temperament in guppies (Poecilia reticulata). Journal of Comparative Psychology 2004:344-356.

Conradt, L., E. J. Bodsworth, T. J. Roper, and C. D. Thomas. 2000. Non-random dispersal in the butterfly Maniola jurtina: implications for metapopulation models. Proceedings of the Royal Society B 267:1505-1510.

Cucherousset, J., J.-M. Paillisson, A. Carpentier, and L. J. Chapman. 2007. Fish emigration from temporary wetlands during drought: the role of physiological tolerance. Archiv für Hydrobiologie 168:169-178.

Davis, J. H. 1943. The natural features of southern Florida, especially the vegetation, and the Everglades. Florida Geological Survey Biological Bulletin 25.

DeAngelis, D. L. 1994. Synthesis: spatial and temporal characteristics of the environment, p. 307-320. In: Everglades: The Ecosystem and Its Restoration. S. M. Davis and J. C. Ogden (eds.). St. Lucie Press, Delray Beach, Florida.

DeAngelis, D. L., W. F. Loftus, J. C. Trexler, and R. E. Ulanowicz. 1997. Modeling fish dynamics and effects of stress in a hydrologically pulsed ecosystem. Journal of Aquatic Ecosystem Stress and Recovery 6:1-13.

DeAngelis, D. L., J. C. Trexler, C. Cosner, A. Obaza, and F. Jopp. 2010. Fish population dynamics in a seasonally varying wetland. Ecological Modelling 221:1131-1137.

DeAngelis, D. L., J. C. Trexler, and W. F. Loftus. 2005. Life history trade-offs and community dynamics of small 
fishes in a seasonally pulsed wetland. Canadian Journal of Fisheries and Aquatic Sciences 62:781-790.

Duever, M. J., J. F. Meeder, L. C. Meeder, and J. M. McCollum. 1994. The climate of south Florida and its role in shaping the Everglades ecosystem, p. 225-248. In: Everglades: The Ecosystem and Its Restoration. S. M. Davis and J. C. Ogden (eds.). St. Lucie Press, Delray Beach, Florida.

Dupuch, A., Y. Paradis, and P. Magnan. 2011. Behavioral responses of prey fishes to habitat complexity and predation risk induce bias in minnow trap catches. Journal of Fish Biology 79:533-538.

Elkin, C. M., and H. Possingham. 2008. The role of landscape-dependent disturbance and dispersal in metapopulation persistence. The American Naturalist 172: 563-575.

Fennema, R. J., C. J. Neidrauer, R. A. Johnson, T. K. MacVicar, and W. A. Perkins. 1994. A computer model to simulate natural Everglades hydrology, p. 249-279. In: Everglades: The Ecosystem and Its Restoration. S. M. Davis and J. C. Ogden (eds.). St. Lucie Press, Delray Beach, Florida.

Frederick, P., D. E. Gawlik, J. C. Ogden, M. I. Cook, and M. Lusk. 2009. The White Ibis and Wood Stork as indicators for restoration of the Everglades ecosystem. Ecological Indicators 9S:S83-S95.

Gaff, H., D. L. DeAngelis, L. J. Gross, R. Salinas, and M. Shorrosh. 2000. A dynamic landscape model for fish in the Everglades and its application to restoration. Ecological Modelling 127:33-52.

Gerritson, J., and J. R. Strickler. 1977. Encounter probabilities and community structure in zooplankton: a mathematical model. Journal of the Fisheries Research Board of Canada 34:73-82.

Goss, C. W., W. F. Loftus, and J. C. Trexler. 2013. Seasonal fish dispersal in ephemeral wetlands of the Florida Everglades. Wetlands. DOI: 10.1007/s13157-013-0375-3.

Gunderson, L. H. 1994. Vegetation of the Everglades: determinants of community composition, p. 323-340. In: Everglades: The Ecosystem and Its Restoration. S. M. Davis and J. C. Ogden (eds.). St. Lucie Press, Delray Beach, Florida.

He, X., and D. M. Lodge. 1990. Using minnow traps to estimate fish population size-the importance of spatialdistribution and relative species abundance. Hydrobiologia 190:9-14.

Henning, J. A., R. E. Gresswell, and I. A. Fleming. 2007. Use of seasonal freshwater wetlands by fishes in a temperate river floodplain. Journal of Fish Biology 71:476-492.

Ho, D. T., V. C. Engel, E. A. Variano, P. J. Schmieder, and M. E. Condon. 2009. Tracer studies of sheet flow in the Florida Everglades. Geophysical Research Letters 36:L09401. DOI: 10.1029/2009GL037355.

Hohausová, E., R. J. Lavoy, and M. S. Allen. 2010. Fish dispersal in a seasonal wetland: influence of anthropogenic structures. Marine and Freshwater Research 61: 682-694.

Jacobson, B., and P. R. Peres-Neto. 2010. Quantifying and disentangling dispersal in metacommunities: How close have we come? How far is there to go? Landscape Ecology 25:495-507.

Jopp, F., D. L. DeAngelis, and J. C. Trexler. 2010. Modeling seasonal dynamics of small fish cohorts in fluctuating freshwater marsh landscapes. Landscape Ecology 25: 1041-1054.

Jordan, F., S. Coyne, and J. C. Trexler. 1997. Sampling fishes in vegetated habitats: effects of habitat structure on sampling characteristics of the $1-\mathrm{m}^{2}$ throw trap. Transactions of the American Fisheries Society 126:1012-1020.

Kobza, R. M., J. C. Trexler, W. F. Loftus, and S. A. Perry. 2004. Community structure of fishes inhabiting aquatic refuges in a threatened Karst wetland and its implications for ecosystem management. Biological Conservation 116:153-165.

Larsen, L. G., and J. W. Harvey. 2010. How vegetation and sediment transport feebacks drive landscape change in the Everglades and wetlands worldwide. The American Naturalist 176:E66-E79.

Leibold, M. A., M. Holyoak, N. Mouquet, P. Amarasekare, J. M. Chase, M. F. Hoopes, R. D. Holt, J. B. Shurin, R. Law, D. Tilman, M. Loreau, and A. Gonzalez. 2004. The metacommunity concept: a framework for multi-scale community ecology. Ecology Letters 7:601-613.

Light, S. S., and J. W. Dineen. 1994. Water control in the Everglades: a historical perspective, p. 47-84. In: Everglades: The Ecosystem and Its Restoration. S. M. Davis and J. C. Ogden (eds.). St. Lucie Press, Delray Beach, Florida.

Liu, Z., J. C. Volin, V. D. Owen, L. G. Pearlstine, J. R. Allen, F. J. Mazzotti, and A. L. Higer. 2009. Validation and ecosystem applications of the EDEN water-surface model for the Florida Everglades. Ecohydrology 2:182-194.

Loftus, W. F., R. A. Johnson, and G. H. Anderson. 1992. Ecological impacts of the reduction of groundwater levels in short-hydroperiod marshes of the Everglades, p. 199-207. In: Proceedings of the First International Conference on Ground Water Ecology. American Water Resources Association, Middleburg, Virginia.

Loftus, W. F., and J. A. Kushlan. 1987. Freshwater fishes of southern Florida. Bulletin of the Florida State Museum: Biological Sciences 31:147-344.

Loveless, C. M. 1959. A study of the vegetation in the Florida Everglades. Ecology 40:1-9.

MacKenzie, B. R., and T. Kiorboe. 1995. Encounter rates and swimming behavior of pause-travel and cruise larval fish predators in calm and turbulent laboratory environments. Limnology and Oceanography 40:1278-1289.

Morales, J. M., D. T. Haydon, J. Frair, K. E. Holsinger, and J. M. Fryxell. 2004. Extraction more out of relocation data: building movement models as mixtures of random walks. Ecology 85:2436-2445.

National Research Council. 2007. Progress Toward Restoring the Everglades. The First Biennial Review-2006. National Academies Press, Washington, D.C.

Obaza, A., D. L. DeAngelis, and J. C. Trexler. 2011. Using data from an encounter sampler to model fish dispersal. Journal of Fish Biology 78:495-513.

Papastamatiou, Y. P., D. P. Cartamil, C. G. Lowe, C. G. Meyer, B. M. Wetherbee, and K. M. Holland. 2011. Scales of orientation, directed walks and movement path structure in sharks. Journal of Animal Ecology 80:864-874.

Parkos, J. J., III, C. R. Ruetz, III, and J. C. Trexler. 2011. Disturbance regime and limits on benefits of refuge use for fishes in a fluctuating hydroscape. Oikos 120:1519-1530.

Pearistine, L. G., E. V. Pearlstine, and N. G. Aumen. 2010. A review of the ecological consequences and management implications of climate change for the Everglades. Journal of the North American Benthological Society 29:1510-1526. 
Poizat, G., and A. J. Crivelli. 1997. Use of seasonally flooded marshes by fish in a Mediterranean wetland: timing and demographic consequences. Journal of Fish Biology 51:106-119.

Ruetz, C. R., III, J. C. Trexler, F. Jordan, W. F. Loftus, and S. A. Perry. 2005. Population dynamics of wetland fishes: spatio-temporal patterns synchronized by hydrological disturbance? Journal of Animal Ecology 74:322-332.

Schick, R. S., S. R. Loarie, F. Colchero, B. D. Best, A. Boustany, D. A. Conde, P. N. Halpin, L. N. Joppa, C. M. McClellan, and J. S. Clark. 2008. Understanding movement data and movement processes: current and emerging directions. Ecology Letters 11:1338-1350.

Snodgrass, J. W., A. L. Bryan, Jr., R. F. Lide, and G. M. Smith. 1996. Factors affecting the occurrence and structure of fish assemblages in isolated wetlands of the upper coastal plain, USA. Canadian Journal of Fisheries and Aquatic Science 53:443-454.

Sokol, E. R., J. M. Hoch, E. Gaiser, and J. C. Trexler. 2013. Metacommunity structure along resource and disturbance gradients in Everglades wetlands. Wetlands. DOI: 10. 1007/s13157-013-0413-1.

Telis, P., H. Henkel, P. Conrads, B. McCloskey, M. Petkewich, N. Matthews, C. Wood, and J. W. Jones. 2012. EDEN: Everglades Depth Estimation Network xy Locator. United States Geological Survey, Jacksonville, Florida. http://sofia.usgs.gov/eden/index.php
Trexler, J. C., and C. W. Goss. 2009. Aquatic fauna as indicators for Everglades restoration: applying dynamic targets in assessments. Ecological Indicators 9S:S108S119.

Trexler, J. C., W. F. Loftus, F. Jordan, J. H. Chick, K. L. Kandl, T. C. McElroy, and O. L. J. Bass. 2001. Ecological scale and its implications for freshwater fishes in the Florida Everglades, p. 153-181. In: The Everglades, Florida Bay and Coral Reefs of the Florida Keys: An Ecosystem Sourcebook. J. W. Porter and K. G. Porter (eds.). CRC Press, Boca Raton, Florida.

Trexler, J. C., W. F. Loftus, and S. A. Perry. 2005. Disturbance frequency and community structure in a twenty-five year intervention study. Oecologia 145:140-152.

UFR Committee. 2004. Guidelines for the Use of Fishes in Research. American Fisheries Society, Bethesda, Maryland.

Viswanathan, G. M., V. Afanasyev, S. V. Buldyrev, E. J. Murphy, P. A. Prince, and H. E. Stanley. 1996. Lévy flight search patterns of wandering albatrosses. Nature 381:413-415.

Wissinger, S. A. 1997. Cyclic colonization in predictably ephemeral habitats: a template for biological control in annual crop systems. Biological Control 10:4-15.

Yurek, S., D. L. DeAngelis, J. C. Trexler, F. Jopp, and D. L. Donalson. 2013. Simulating mechanisms for dispersal, production and stranding of small forage fish in temporary wetland habitats. Ecological Modelling 250:391-401. 